\title{
Pregnancy-associated and placental proteins in the placental tissue of normal pregnant women and patients with pre-eclampsia at term
}

\author{
Nick A Bersinger, Nigel Groome ${ }^{1}$ and Shanthi Muttukrishna ${ }^{2}$ \\ Department of Obstetrics and Gynaecology, University of Berne, Berne, Switzerland, ${ }^{1}$ School of Biological and Molecular Sciences, \\ Oxford Brookes University, Oxford, UK and ${ }^{2}$ Nuffield Department of Obstetrics and Gynaecology, John Radcliffe Hospital, Oxford, UK \\ (Correspondence should be addressed to N A Bersinger, Reproductive and Perinatal Medicine Research Laboratory, Inselspital G3-855 KKL, Berne, \\ CH-3010, Switzerland; Email: nick.bersinger@dkf2.unibe.ch)
}

(Shanthi Muttukrishna is currently at Department of Obstetrics and Gynaecology, University College London, Royal Free-UCL Medical School, London WC1E 6HX, UK)

\begin{abstract}
Objective: Pre-eclampsia is a placental disease of unknown cause. Maternal circulating concentrations of a number of protein markers are altered (mainly increased) in pre-eclampsia in comparison with controls of matched gestational age. Inhibin A and activin A were found to be elevated even before the onset of the disease. The aim of this study was to compare the levels of inhibin A, activin A: follistatin ratio, leptin, pregnancy-associated plasma protein-A (PAPP-A), human placental lactogen (HPL), placenta growth factor (PLGF) and pregnancy-specific $\beta 1$-glycoprotein (SP1) in placental extracts of normal pregnant women and pre-eclampsia patients at term.

Methods: Placental tissue from normal pregnancies $(n=14)$ and patients with pre-eclampsia $(n=13)$ were collected at term $\left(\geq 37\right.$ weeks of gestation) and stored at $-80^{\circ} \mathrm{C}$. The frozen tissue pieces were homogenised and the above-mentioned proteins were measured by specific enzyme-linked immunosorbent assays.

Results: Placental contents of inhibin A and PAPP-A were significantly higher $(P<0.05)$ in preeclampsia placental extracts compared with the controls. Activin A:follistatin ratio was higher (23) in pre-eclampsia extracts than in the controls (15). Leptin, PLGF, SP1 and HPL levels were not altered in the term pre-eclampsia placenta. Inhibin A and PAPP-A contents were increased in the placental extracts of pre-eclampsia patients.

Conclusion: Our data suggest that the placenta, possibly by a compensatory mechanism, is at least in part responsible for the altered serum levels observed in pre-eclampsia.
\end{abstract}

European Journal of Endocrinology 147 785-793

\section{Introduction}

Pre-eclampsia develops in late pregnancy and may result in maternal and fetal morbidity and mortality. Its cause is as yet unknown. The only treatment for pre-eclampsia is the delivery of the placenta, after which the symptoms regress rapidly suggesting it is a placental disease. It is associated with poor placentation with incomplete physiological adaptation of the spiral arteries, which prevents them from dilating to accommodate the increased utero-placental blood flow of late gestation (1). It is believed that the maternal syndrome of pre-eclampsia (hypertension, proteinuria, oedema) results from a generalised inflammatory response, which causes maternal endothelial dysfunction (2). This response is triggered by circulating factor(s), possibly released from the placenta by apoptosis of the syncytiotrophoblast.

The concentrations of several placental proteins, inflammatory cytokines and growth factors are altered in the maternal circulation of women with preeclampsia. Inhibins $(\alpha-\beta$ dimers $)$ and activins $(\beta-\beta$ dimers) are glycoprotein hormones belonging to the transforming-growth factor $\beta$ superfamily. Follistatin is a high-affinity activin-binding protein. We and several others have previously shown that the levels of activin $A(\beta A-\beta A$ dimer $)$ and inhibin $A(\alpha-\beta A$ dimer) are significantly elevated in the circulation of women who have developed pre-eclampsia (3-5), and in women who subsequently develop pre-eclampsia compared with gestational age-matched control pregnant women $(6-9)$. The placenta produces inhibin A 
and activin A with a marked increase towards term $(10-12)$.

The possible occurrence of abnormal serum levels of the 'new generation' pregnancy proteins, pregnancyassociated plasma protein A(PAPP-A) and pregnancyspecific $\beta 1$-glycoprotein (SP1), have been previously studied in detail (for review see 13). Raised PAPP-A concentrations in pre-eclampsia have been reported earlier $(14,15)$. However, some discrepancy has remained (16) and PAPP-A, as well as SP1, have not been investigated further. Following a preliminary study (17), we were able to confirm that serum PAPP-A but not SP1 levels were elevated in pre-eclampsia patients consistent with previous reports $(14,15,18)$.

Another hormone with a physiological role outside pregnancy but with increased serum levels during gestation is leptin, the product of the $o b$ gene, which was first described in 1994 (19). Leptin is released by peripheral adipocytes (20) and its serum levels correlate with body mass (21). In pregnancy, however, it is also produced to a considerable extent by the placenta (22), resulting in increasing concentrations with advancing gestation until the mid-third trimester (23). It has been suggested that the placenta produces increased amounts of leptin under hypoxic conditions (24). Hence this placental, supposedly body massindependent fraction of leptin (25) will be of interest in the investigation of pre-eclampsia, a condition where there is placental hypoxia.

Placenta growth factor (PLGF) is a recently described protein, which shares structural and functional properties with the vascular endothelial growth factor (VEGF). PLGF, in contrast to VEGF and the above-mentioned markers, was reported to be decreased in the serum of pre-eclampsia patients (26), which could be explained by the observation that VEGF was up- and PLGF was down-regulated by hypoxia in various cancers and in vitro in trophoblast-derived cell lines $(27,28)$. The similarities between PLGF and VEGF, which are mainly produced by endothelial cells besides its synthesis in the trophoblast (29), render an assignment of PLGF production exclusively to the placenta in pregnant women rather improbable.

Maternal endothelial cell dysfunction is thought to be responsible for the observed life-threatening symptoms of pre-eclampsia $(30,31)$. Nevertheless, it is speculated that the placenta is at the origin of the disease with insufficient trophoblast invasion and its consequences on vasculogenesis and oxygen delivery. Most studies have reported changes in placenta-derived factors in the maternal circulation. We have set out to investigate if there is any difference in the placental content of trophoblast-specific and associated markers in pre-eclampsia compared with normal pregnancies. Activin A was recently reported to be increased in placental (but not in other gestational) tissue of preeclampsia patients (32). Our first group included SP1 and human placental lactogen (HPL, originating specifically from the placenta), and the second group contains markers that are produced mostly but not exclusively by the placenta in pregnancy (PAPP-A, inhibin A, activin A, follistatin, PLGF, leptin). Placental markers whose levels are reflected in the circulation can be useful as biochemical markers of pre-eclampsia before the onset of the disease.

\section{Materials and methods}

\section{Placental tissue and extraction}

Tissue samples were randomly cut from different parts of 27 placentae, extensively rinsed in sterile saline, snap frozen in liquid nitrogen and stored at $-80^{\circ} \mathrm{C}$ at the John Radcliffe Hospital in Oxford, UK. Ethical approval was obtained from the local ethics committee for this study. Fourteen of these placentae were from control pregnancies at term ( $\geq 37$ weeks of gestation) and 13 from women with pre-eclampsia at term ( $\geq 37$ weeks of gestation). Pre-eclampsia was defined as new, sustained diastolic blood pressure above $90 \mathrm{mmHg}$ and new, sustained proteinuria with $500 \mathrm{mg}$ protein $/ 24 \mathrm{~h}$ urinary sample in the absence of urinary tract infection. Pre-eclamptic patients in this study fitted these criteria. The maternal age was 30.7 \pm 4.9 (s.D.) in the control and $30.8 \pm 2.7$ years in the preeclampsia group, and the maternal weight at delivery was $88.5 \pm 9.5$ (s.D.) in the control and $88.0 \pm 13.5 \mathrm{~kg}$ in the pre-eclampsia group. Both groups included five primigravidae, and there was no difference in fetal weight, i.e. no infants were diagnosed as small for gestational age. Labour was uneventful in all cases.

The placental villi $(164-559 \mathrm{mg}$ wet weight) were washed twice in 200-400 ml Tris-Cl buffer, $20 \mathrm{mM}$, $\mathrm{pH} 7.4, \mathrm{NaCl}, 100 \mathrm{mM}$ and homogenised manually in four volumes $(\mathrm{w} / \mathrm{v})$ of the same buffer containing EDTA-free serine-/cysteine-protease inhibitor cocktail (Roche Biochemicals, diluted according to the manufacturer's instructions) in a serrated glass-Teflon homogeniser. The supernatant extract was collected after centrifugation $\left(6000 \mathrm{~g}, 20 \mathrm{~min}, 4^{\circ} \mathrm{C}\right)$ and the total protein concentration determined with the Bradford assay (Pierce, Lausanne, Switzerland) using human serum albumin as a standard. Extracts were divided into two to three aliquots and stored at $-40{ }^{\circ} \mathrm{C}$ until quantitative analyses were performed in batch.

\section{Analytical assay methods}

All proteins were quantified in the extracts using double-antibody enzyme-linked immunosorbent assays (ELISA) based on 96-well plates. The methods were following either two-incubation (enzyme-labelled second antibody) or three-incubation (biotinylated second antibody followed by streptavidin-enzyme conjugate) protocols, with washing steps using phosphate-buffered 
saline (PBS) containing Tween-20 (Sigma) at 0.1\% $(\mathrm{v} / \mathrm{v})($ PBST) between steps.

\section{PAPP-A and SP1}

These 'new-generation' markers were determined in two-step systems developed in our laboratory as previously described for PAPP-A (33) and for SP1 (34). For PAPP-A, the capture antibody had to be further purified by negative affinity chromatography (33). Calibrators for both assays were prepared from pooled pregnancy serum standardised against the international reference preparation 78-610 obtained from the World Health Organisation (Geneva, Switzerland). The placental extracts were assayed in duplicate at high dilutions (1:200 for PAPP-A and 1:2500 for SP1) since these tests were initially developed for use in early pregnancy. Second antibodies were covalently bound to horseradish peroxidase (HRP) and the substrate cocktail contained perborate and ortho-phenylene diamine $(0.8 \mathrm{mg} / \mathrm{ml})$. Intra- and interassay coefficients of variance at mid-standard concentration were 2.3 and $7.2 \%$ for PAPP-A and 4.1 and $8.7 \%$ for SP1 respectively. Spiking recovery for PAPP-A,

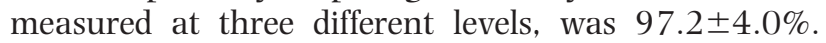
Matrix effects in the SP1 assay were avoided by the extremely high dilutions of the placental extract and calibrator serum in buffer containing $2 \%(\mathrm{w} / \mathrm{v})$ bovine serum albumin (BSA); spiking recovery was $97.7 \pm 4.6 \%$.

\section{HPL}

The two-step double-antibody ELISA used for HPL was also developed in our laboratory and described in detail elsewhere (35). First (coating) and second (HRP-labelled) polyclonal antibodies were obtained from Dako (Glostrup, Denmark) and used without further modification. Calibrators from DPC (Los Angeles, CA, USA) were used as standards after further dilution in the assay buffer. Detection was as for PAPPA/SP1. The assay has been demonstrated to yield comparable values for serum as well as for cell culture supernatants (36).

\section{Inhibin A}

Inhibin A was measured using a two-site ELISA as previously validated for placental extracts (11). The minimum detection limit of this assay for human recombinant inhibin A (National Institute for Biological Standards, Potters Bar, Herts, UK) was 2 pg/ml. Intraand interassay coefficients of variation were $4.5 \%$ and $5.1 \%$ respectively.

\section{Activin A}

Activin A was measured using a two-site ELISA as described before (12). It measures 'total' activin A (follistatin bound+unbound activin A, (37)). Dissociation of the binding proteins occurs in the sample preparation step as described before (38). The assay has been previously validated for placental extracts (12). The detection limit of this assay for human recombinant activin A (Genentech, San Francisco, CA, USA) was $50 \mathrm{pg} / \mathrm{ml}$. Intra- and interassay coefficients of variation were $8.5 \%$ and $9.8 \%$ respectively.

\section{Follistatin}

Follistatin was similarly measured as 'total' analyte (free+activin bound) using a two-site ELISA as described elsewhere (39). A dissociating buffer is used in the assay to remove the interference from binding proteins. The sensitivity of this assay was $20 \mathrm{pg} / \mathrm{ml}$. Intra- and interassay coefficients of variation were $6.8 \%$ and $9.15 \%$ respectively. Placental homogenates diluted in parallel to the standards, and a spike recovery of $104 \pm 6.4 \%$ was found for recombinant follistatin in placental homogenates.

\section{PLGF}

For this protein, an ELISA was set up in our laboratory with antibodies purchased as 'matched pairs' (from R\&D Systems, Abingdon, UK). Microplate wells were coated $(100 \mu \mathrm{l})$ with the capture antibody at $2 \mu \mathrm{g} / \mathrm{ml}$ in PBS overnight at $4{ }^{\circ} \mathrm{C}$ and excess sites were blocked with BSA $(0.5 \mathrm{mg} / \mathrm{ml})$ in PBS for $2 \mathrm{~h}$ at room temperature. Placental extracts were diluted 1:5 in Blotto $(0.5 \%$ w/v non-fat milk proteins in PBS, obtained from Pierce) and the plates incubated at $30^{\circ} \mathrm{C}$ for $2 \mathrm{~h}$ with slow shaking (300 r.p.m.) in a Thermostar dry shaker/incubator. After washing the plates with PBST, the detection antibody (200 ng/ml in Blotto) was added and the wells incubated for another $2 \mathrm{~h}$ as before. We have found that antibody binding at $30^{\circ} \mathrm{C}$ was higher than at $37^{\circ} \mathrm{C}$ and, in addition, more consistent than at $25^{\circ} \mathrm{C}$ or room temperature (authors' unpublished observation). After another washing step, an incubation (45 min, $30{ }^{\circ} \mathrm{C}, 300$ r.p.m.) with streptavidin-conjugated HRP compound (Southern Biotech Associates, Birmingham, AL, USA), diluted 1:4000 in Blotto, was performed. After extensive washing (five steps) the colour was developed using single substrate 3,3',5,5'-tetramethyl benzidine solution (TMB; Zymed, USA) in a timed sequence at room temperature. The reaction was stopped after 20-30 min with $2 \mathrm{M}$ sulphuric acid, the plates were shaken and the optical absorbance was read at $450 \mathrm{~nm}$ against a $595 \mathrm{~nm}$ reference in a BioRad (Richmond, CA, USA) model 550 microplate reader. The calibrator (recombinant human PLGF) was obtained as a lyophilisate from R\&D Systems and 
diluted in Blotto to a standard range between 1000 and $15.6 \mathrm{pg} / \mathrm{ml}$ in 1:2 serial steps. Intra- and interassay coefficients of variance at $100 \mathrm{pg} / \mathrm{ml}$ were 7.9 and $11.3 \%$ respectively.

\section{Leptin}

This protein was similarly assayed with an in-house three-step incubation ELISA and TMB detection method using a matched monoclonal antibody pair and recombinant human standard from R\&D Systems (40). The intra- and interassay coefficients of variance were 2.7 and $8.9 \%$ respectively.

\section{Statistical analysis}

For every tested marker the analyte content was expressed for each extract as per mg total protein. These specific values were compared between the two groups with the Student's t-test after logarithmic transformation (except for the activin A to follistatin ratio which was not transformed) using a scientific statistics package (InStat; GraphPad, San Diego, CA, USA). Correlations between marker levels within the groups were obtained by linear regression analysis without logarithmic transformation. A $P$ value of 0.05 was used as a cut-off for significance in all tests.

\section{Results}

The placental extract contents of PAPP-A, SP1, HPL, PLGF, inhibin A, activin A, follistatin and leptin, expressed per $\mathrm{mg}$ protein, are listed in Table 1 . PAPP-A was significantly increased $(P=0.0391)$ in the pre-eclampsia group compared with the unaffected controls whilst HPL and SP1 were not altered in preeclampsia patients (Fig. 1A-C). Placental content of inhibin A was significantly elevated $(P=0.0453)$ whilst activin A was not significantly altered (Fig. 1E and F) in pre-eclampsia patients compared with the controls. Follistatin levels were not different between controls and pre-eclampsia patients (Fig. 1G). PLGF was not altered in our samples of pre-eclampsia cases compared with controls (Fig. 1D). Leptin presented an extremely wide distribution particularly in the preeclampsia group (Fig. 1H). Placental leptin did marginally correlate with the maternal weight at delivery in the pre-eclampsia group $(r=0.685, P=0.0419)$ but not in the control group. However, maternal weight at booking (early pregnancy) did not correlate with the leptin levels measured in the placenta.

In the pre-eclampsia group, there were no significant correlations between the parameters studied. In the control group, there was a significant positive correlation between inhibin A and activin A $(r=0.535$, $P<0.05)$, inhibin A and PAPP-A $(r=0.557, P<$ 0.05), inhibin A and leptin $(r=0.575, P<0.05)$, activin $A$ and leptin $(r=0.91, P<0.001)$ and PAPP-A and leptin $(r=0.61, P<0.05)$ (Fig. 2). The correlation coefficients $r$ and the $P$ values for the individual groups are shown in Table 2.

\section{Discussion}

After the onset of pre-eclamptic symptoms, serum levels of PAPP-A $(14,15,17)$, inhibin A and activin A (3) are increased in comparison with normal pregnancies whilst PLGF levels are decreased (26) and the concentrations of SP1 and HPL are unchanged $(17,18,41)$. In this study, we have measured the concentrations of these proteins in placental extracts to specifically study the changes in the placenta in pre-eclampsia as serum levels reflect cumulative changes in all potential sources. We found that the placental content reflected the serum pattern for PAPP-A and inhibin A in preeclampsia, suggesting that the placenta is a source of the elevated circulating concentrations of these proteins in pre-eclampsia. The molar ratio of activin A to follistatin is $\geq 6.85$ (median 15.8; Fig. 3) in normal pregnancy indicating that a considerable amount of biologically active 'free' activin $\mathrm{A}$ is available in the placenta. In pre-eclampsia, the increased activin A content further increased the molar ratio between activin A and follistatin (median 23.0; Fig. 3). In the maternal serum at term, however, follistatin has been reported to be in a tenfold excess over activin A (42), thus strongly

Table 1 Content of marker proteins (expressed per mg protein) in placental tissue from control and pre-eclampsia pregnancies. Values are medians and range.

\begin{tabular}{llll}
\hline Protein & Controls $(n=14)$ & Pre-eclampsia $(n=13)$ \\
\hline PAPP-A $(\mathrm{mlU} / \mathrm{mg})$ & $1.37(0.61-2.95)$ & $1.99(1.07-4.68)$ & $\boldsymbol{P}$ \\
SPI $(\mu \mathrm{g} / \mathrm{mg})$ & $0.96(0.43-1.28)$ & $0.98(0.58-1.39)$ & 0.0391 \\
HPL $(\mu \mathrm{g} / \mathrm{ml})$ & $7.18(3.58-11.72)$ & $8.11(4.31-12.92)$ & 0.1991 \\
PLGF $(\mathrm{pg} / \mathrm{mg})$ & $300(156-642)$ & $373(255-618)$ & 0.6768 \\
Inhibin A $(\mathrm{pg} / \mathrm{mg})$ & $335(164-692)$ & $545(224-1339)$ & 0.1510 \\
Activin A $(\mathrm{pg} / \mathrm{mg})$ & $2777(1175-8271)$ & $4561(1427-9752)$ & 0.0453 \\
Follistatin $(\mathrm{pg} / \mathrm{mg})$ & $291(231-395)$ & $302(150-367)$ & 0.1395 \\
Leptin $(\mathrm{pg} / \mathrm{mg})$ & $276(157-2529)$ & $980(147-4797)$ & 0.9624 \\
\hline
\end{tabular}

$P$ values were obtained with the Student's $t$-test (see Materials and methods and Fig. 1). 
A

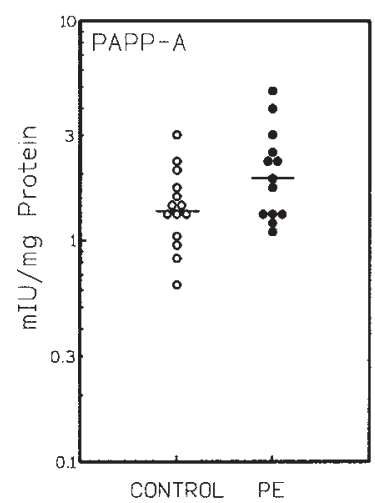

E

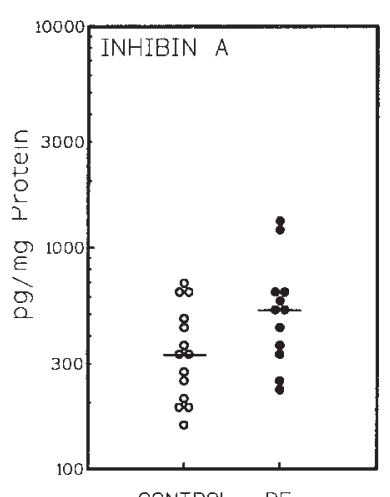

$\mathrm{B}$

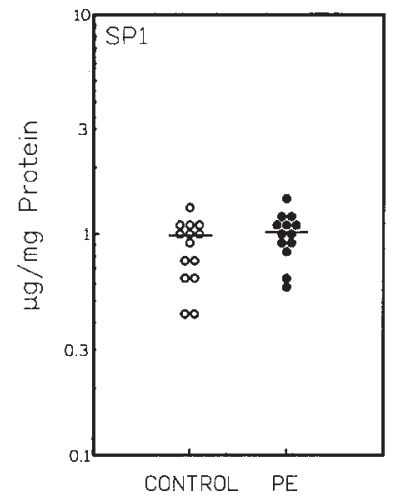

F

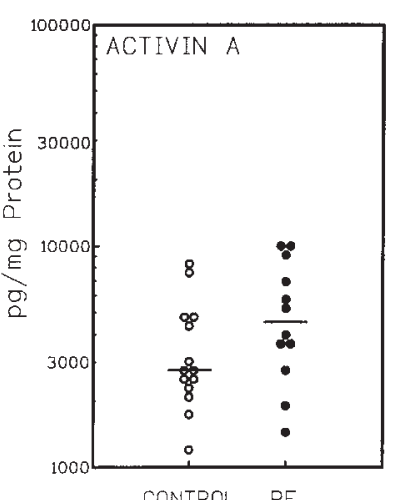

C

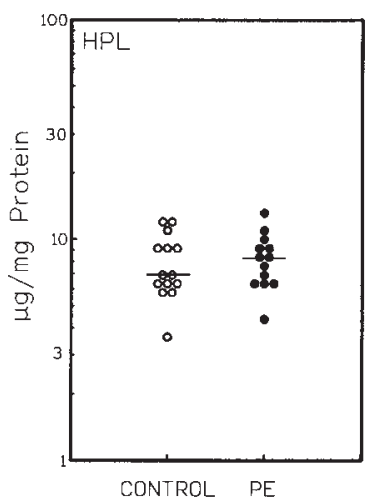

G

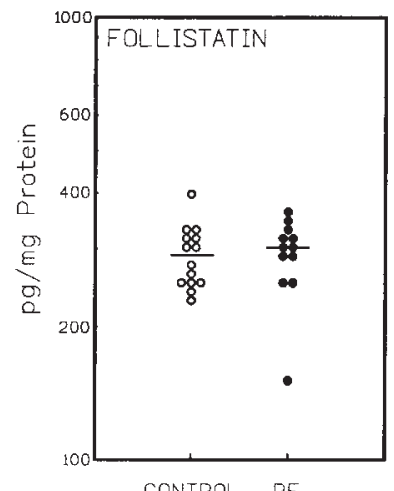

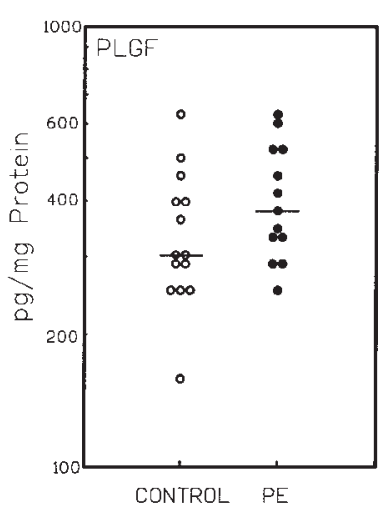

$\mathrm{H}$

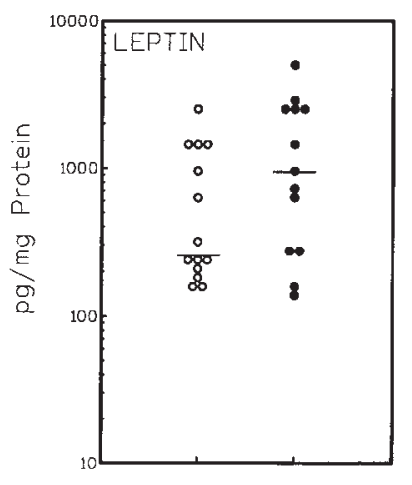

Figure 1 Specific content of marker proteins in control and pre-eclampsia (PE) placental extracts, expressed as per mg total protein in the extract. Please note the logarithmic scale. (A) PAPP-A; (B) SP1; (C) HPL; (D) PLGF; (E) inhibin A; (F) activin A; (G) follistatin; (H) leptin. The horizontal bars are medians.

reducing the level of free activin A. This suggests that free activin A may therefore have autocrine/paracrine actions in the placenta and could contribute to the pathology of pre-eclampsia. The increased activin A

Table 2 Correlation coefficients $(r)$ and significance $(P)$ between various markers in control and pre-eclampsia samples as analysed by linear regression.

\begin{tabular}{lrrrrrr}
\hline & \multicolumn{2}{c}{ Controls $(n=14)$} & & \multicolumn{2}{c}{$\begin{array}{c}\text { Pre-eclampsia } \\
(n=13)\end{array}$} \\
\cline { 2 - 3 } \cline { 6 - 7 } Analysis & $r$ & $P$ & & $r$ & $P$ \\
\hline PAPP-A vs inhibin A & $\mathbf{0 . 5 5 7}$ & $\mathbf{0 . 0 3 8 5}$ & & 0.418 & 0.1763 \\
PAPP-A vs activin A & 0.520 & 0.0569 & & 0.483 & 0.1114 \\
Inhibin A vs activin A & $\mathbf{0 . 5 3 5}$ & $\mathbf{0 . 0 4 8 8}$ & & 0.363 & 0.2468 \\
Follistatin vs activin A & 0.119 & 0.6846 & & 0.485 & 0.1098 \\
PAPP-A vs PLGF & -0.483 & & 0.0806 & & 0.040 & 0.8964 \\
Inhibin vs PLGF & -0.432 & 0.1233 & & 0.133 & 0.6809 \\
Leptin vs PLGF & -0.265 & & 0.3593 & & 0.014 & 0.9648 \\
PAPP-A vs leptin & $\mathbf{0 . 6 1 0}$ & $\mathbf{0 . 0 2 0 6}$ & & 0.268 & 0.3766 \\
Inhibin A vs leptin & $\mathbf{0 . 5 7 5}$ & $\mathbf{0 . 0 3 1 7}$ & & -0.317 & 0.3159 \\
Activin A vs leptiin & $\mathbf{0 . 9 1 0}$ & $\mathbf{0 . 0 0 0 1}$ & & 0.115 & 0.0963 \\
\hline
\end{tabular}

Statistically significant associations are in bold. to follistatin ratio in the placenta, which is contrary to the circulation, also confirmed that our placental extracts had not been contaminated with maternal serum.

There is evidence for the feto-placental unit to be the major source of increased concentrations of inhibin A and activin $A$ in the maternal circulation in early pregnancy (43). We have shown that term cytotrophoblasts in culture secrete inhibin A and activin A (44). Trophoblast dysfunction is the primary problem in preeclampsia (1). It is thought that the maternal syndrome may be caused by oxidative stress (45) associated with spiral artery disease. It is unclear why inhibin A and activin $A$ are increased in pre-eclampsia and whether they contribute to the aetiology of the disease. However, our recent study (44) shows that placental trophoblast secretion of inhibin A and activin A are stimulated in the presence of inflammatory cytokines that are increased in pre-eclampsia. Therefore, the rise in placental contents of inhibin A could be due to the autocrine/paracrine effect of high levels of inflammatory cytokines in pre-eclampsia. Inflammatory cells 
A
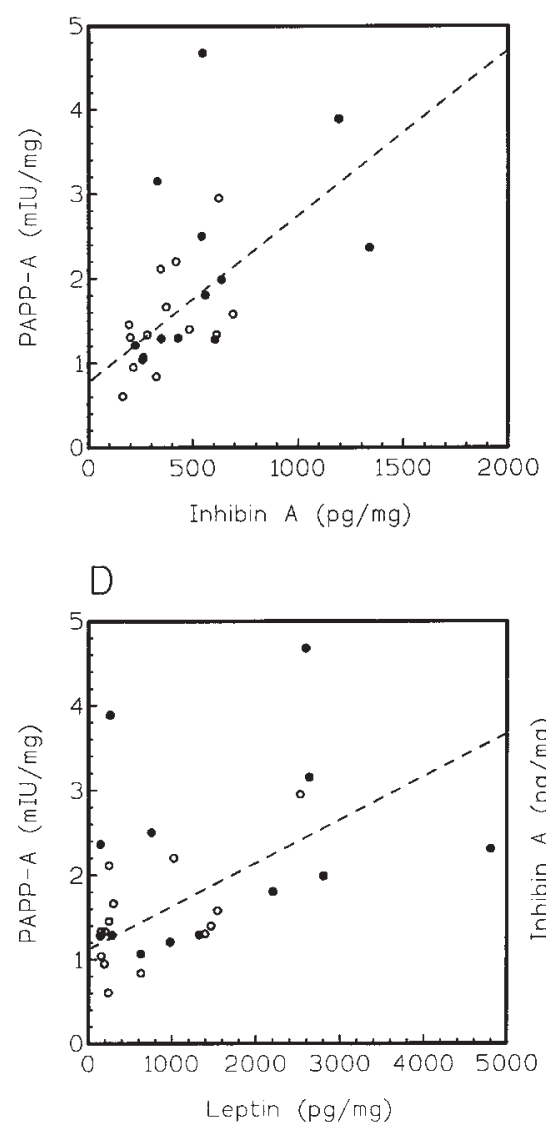

$\mathrm{B}$

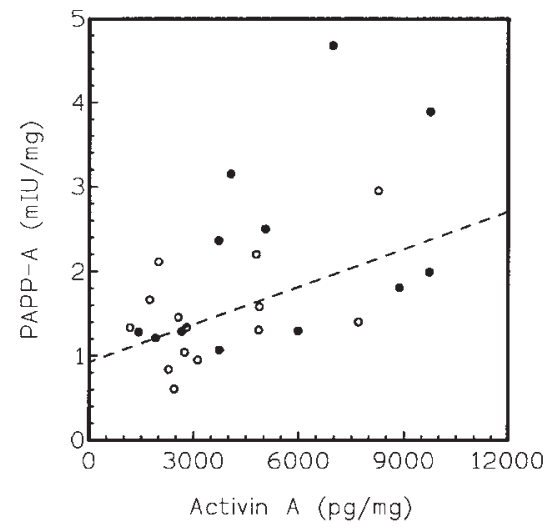

E

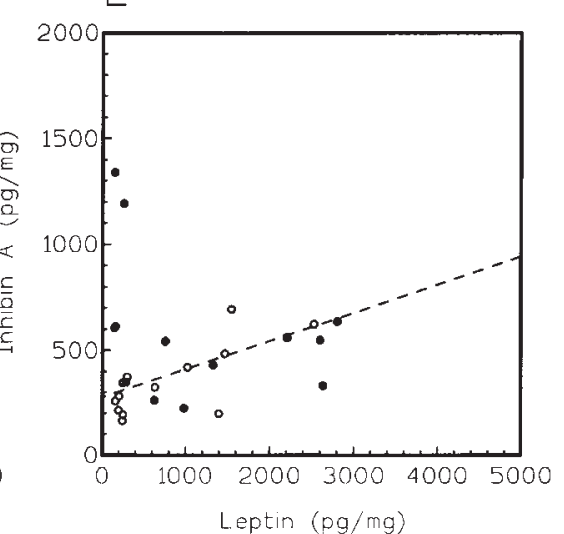

C

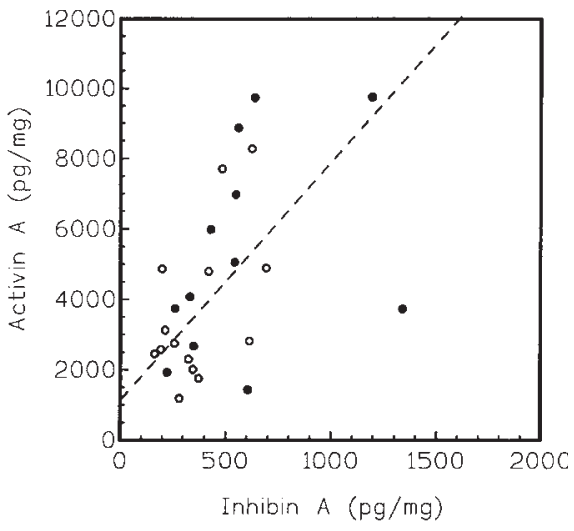

F

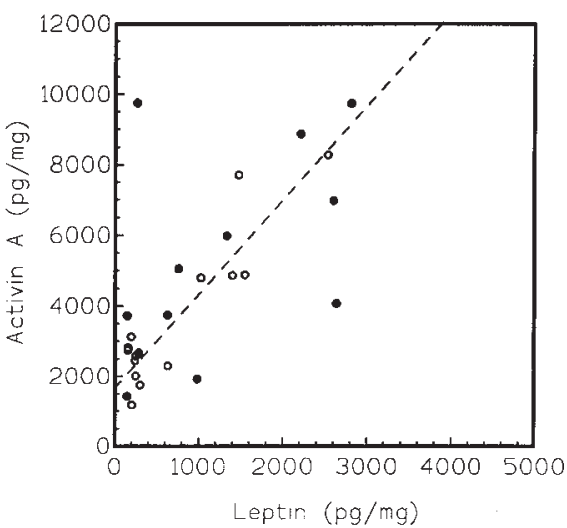

Figure 2 Correlations between different marker proteins in placental extracts. Controls $(O)$; pre-eclampsia $(\bullet)$. (A) PAPP-A vs inhibin A; (B) PAPP-A vs activin A; (C) activin A vs inhibin A; (D) PAPP-A vs leptin; (E) inhibin A vs leptin; (F) activin A vs leptin. Regression lines are shown for the control samples only $(n=14)$; no significance was obtained in the pre-eclampsia group alone $(n=13)$ for any combination of proteins (see Table 2).

also produce activin A (46). Peripheral mononuclear cell secretion of activin $A$ is increased in culture in the presence of inflammatory cytokines (47). Preeclampsia is also characterised by an intense systemic inflammatory response (2). Hence activin A may be derived from circulating inflammatory cells as well as the placenta. This may explain the lack of significance in the rise of activin A in pre-eclamptic placental extracts. The placenta does not exclusively produce PAPP-A and inhibin A, activin A and follistatin; the serum concentrations of these proteins increase during the third trimester in normal pregnancy when placental growth reaches a plateau and placental markers such as SP1 and HPL do not increase any further. In this study, however, it is precisely the placental content of PAPP-A and the inhibins that were increased in the pre-eclampsia cases compared with the controls. Moreover, positive correlations were observed between PAPP-A and inhibin/activin A (Table 2). On the other hand, there was no significant relationship between any measured proteins in this study in pre-eclamptic placentae (Table 2), suggesting that the changes in pre-eclampsia are not parallel to the controls. There are several factors altered in pre-eclampsia (e.g. oxygen tension, cytokines and growth factors etc.) that could cause changes in the synthesis and secretion of placental proteins. It is evident from this study that in the diseased placenta the production on inhibin A, activin A, leptin and PAPP-A are differently controlled.

A semi-quantitative immunohistochemical study has shown increased staining for the inhibin $\alpha$ subunit in the cytoplasm of syncytiotrophoblasts in pre-eclampsia when compared with placentae from unaffected pregnancies (48), an observation in agreement with this study as well as with the elevated contents of inhibin $A(\alpha-\beta A)$ and activin $A(\beta A-\beta A)$ in the maternal serum. However, immunostaining with inhibin $\alpha$ subunit and or $\beta A$ subunit does not confirm the presence of the biologically active dimeric inhibin $A$ and/or activin A in the placenta. Recently, placental extracts from pre-eclampsia patients have been shown to have increased levels of activin A at term and pre-term compared with normal term controls (32). Whilst, in our 


\section{ACTIVIN A : FOLLISTATIN}

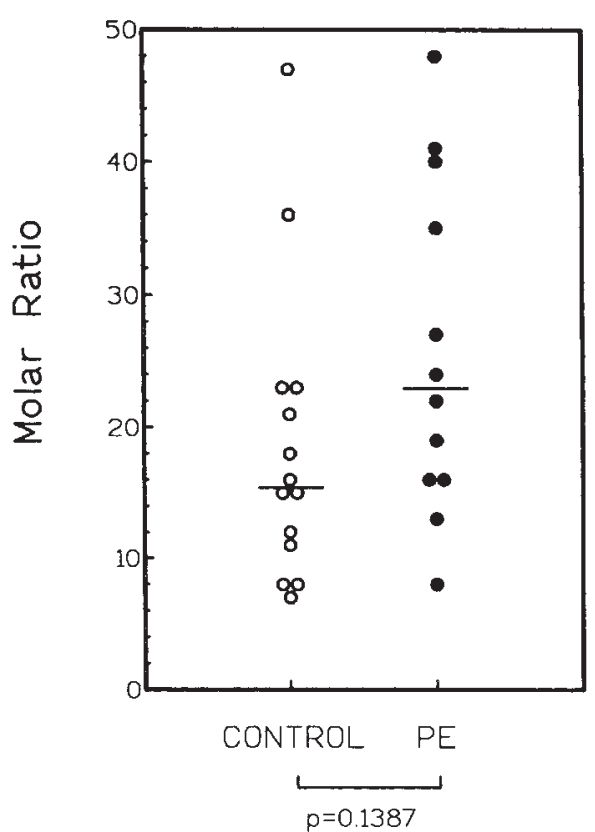

Figure 3 Molar ratio between activin A (molecular weight $=24 \mathrm{kDa}$ ) and follistatin (molecular weight $=35 \mathrm{kDa}$ ) in control and pre-eclampsia groups. Horizontal bars indicate the medians.

study, the levels of activin A in the placental extracts at term in the cases were higher than in the controls, this did not reach statistical significance $(5.60 \pm 0.78 \mathrm{ng} / \mathrm{mg}$ protein vs $3.67 \pm 0.58 \mathrm{ng} / \mathrm{mg}$ protein respectively). This difference in the observation may be due to the severity of the disease or tissue homogenisation method. However, this is the first study to investigate the concentrations of dimeric inhibin A and activin A:follistatin ratio in the placenta in pre-eclampsia. The increased placental content of inhibin A and PAPP-A in pre-eclampsia, together with the reduced levels of PLGF in the serum of affected pregnancies, suggests that the placenta is playing specific control functions even in the third trimester, and that the increased serum levels of these markers are not solely due to placental breakdown and increased release of components into the circulation, but also a result of increased placental production in preeclampsia. Placental compensation mechanisms that have been suggested in another pathological context (Down's syndrome) (49-51) may also function in pre-eclampsia as the placenta adjusts to an initial abnormal situation (e.g. invasion, small fetus or, in our case, secondarily to the changes induced by endothelial dysfunction).

Recent studies have shown that, in pregnancy, maternal circulating levels of leptin were higher than in non-pregnant controls (23), and that in pre-eclampsia these levels were further increased in comparison with normal pregnant women even before the onset of the disease $(52,53)$. The fetal compartment also contains higher levels of leptin, as shown in cord serum concentrations of fetuses of pre-eclamptic mothers (54). This is the first study to report leptin levels in placental extracts from pre-eclampsia patients and its strong correlation with PAPP-A and activin A. We speculate that the placental production of leptin in pregnancy has its specific role, which could be endocrinologically connected to the stimulation of follicle-stimulating hormone (FSH) and luteinizing hormone (55), directly or via activin A.

The continued rising levels of PAPP-A and activin A in the third trimester of pregnancy may be linked to FSH, leptin and nutrition (56). We did not observe a statistically significant correlation between the maternal weight at delivery and the placental leptin content, indicating that this fraction is not dependent on the mass of adipose tissue. In the maternal serum, however, a strong correlation between leptin and the percentage of body fat was reported to persist even in late pregnancy (23) as in non-pregnant women (21). This is casting doubt on the physiological importance of the placental contribution to the role of this hormone, and may point towards a paracrine action as suggested elsewhere (57). The role of leptin in pregnancy, and its significance in pre-eclampsia and intrauterine growth retardation (IUGR) is not clear and requires further investigation. The expected negative correlation between leptin and PLGF, from the suggested up-regulation of the former and down-regulation of the latter under hypoxia, was only marginally demonstrated and the role of oxygen tension remains unclear. The situation is further complicated by the observation that mRNA levels for PLGF in placental extracts were elevated in pregnancies complicated by IUGR. The report suggests that 'placental hyperoxia' plays a role in IUGR and, to a lesser extent, in pre-eclampsia (58), supporting our observation.

In summary, it is increasingly evident that preeclampsia is a multisystem disease and the placental function is affected in the disease. Placental content of inhibin A and PAPP-A are significantly altered in pre-eclampsia patients compared with normal pregnant women at term. However, the abnormal levels of these growth factors, hormones and proteins in the maternal circulation may be a result of the different systems that are affected in pre-eclampsia. This could include differences in the cellular structure and content of endothelial cells, damaged to a varying degree, and modified haemodynamic patterns and vessel branching. Future studies on these proteins in pre-eclampsia should investigate the relative contribution of the immune system, endothelial cells, renal clearance and placental and decidual production to understand the mechanism(s) involved in the pathogenesis and altered maternal circulatory proteins in pre-eclampsia. 


\section{Acknowledgements}

Our thanks go to Ursula Huber in the Endocrinology Research Laboratory at the University of Berne, for skilled technical help in the running of the ELISA tests. We also thank the National Institute for Biological Standards for providing the human recombinant inhibin A standard. The Wellcome Trust is acknowledged for supporting $\mathrm{S} \mathrm{M}$.

\section{References}

1 Redman CW. Current topic: Pre-eclampsia and the placenta. Placenta $199112301-308$.

2 Redman CW, Sacks GP \& Sargent I. Pre-eclampsia: an excessive maternal inflammatory response to pregnancy. American Journal of Obstetrics and Gynecology 1999180 499-506.

3 Muttukrishna S, Knight PG, Groome NP, Redman CW \& Ledger WL. Activin A inhibin A as possible endocrine markers for pre-eclampsia. Lancet 1997349 1285-1288.

4 Petraglia F, Aguzzoli L, Gallinelli A, Florio P, Zonca M, Benedetto C et al. Hypertension in pregnancy: changes in activin A maternal serum concentration. Placenta $199516447-454$.

5 Fraser RF, McAsey ME \& Coney P. Inhibin-A and pro- $\alpha \mathrm{C}$ are elevated in preeclamptic pregnancy and correlate with human chorionic gonadotrophin. American Journal of Reproductive Immunology $19984037-42$.

6 Cuckle H, Sehmi I \& Jones R. Maternal serum inhibin A can predict pre-eclampsia. British Journal of Obstetrics and Gynaecology $19981051101-1103$.

7 Aquilina J, Barnett A, Thompson O \& Harrington K. Secondtrimester maternal serum inhibin A concentration as an early marker for preeclampsia. American Journal of Obstetrics and Gynecology $1999 \mathbf{1 8 1} 131-136$.

8 Silver HM, Lambert GM, Star JA, Hogan J \& Canick JA. Comparison of maternal serum total activin A and inhibin A in normal, pre-eclamptic, and non-proteinuric gestationally hypertensive pregnancies. American Journal of Obstetrics and Gynecology 1999 $1801131-1137$.

9 Muttukrishna S, North RA, Morris J, Schellenberg JC, Taylor RS, Asselin J et al. Serum inhibin A and activin A are elevated prior to the onset of pre-eclampsia. Human Reproduction $2000 \mathbf{1 5}$ $1640-1645$

10 Petraglia F, Garuti GC, Calza L, Roberts V, Giardino L, Genazzani AR et al. Inhibin subunits in human placenta: localisation and messenger ribonucleic acid levels during pregnancy. American Journal of Obstetrics and Gynecology $1991 \mathbf{1 6 5} 750-758$.

11 Muttukrishna S, George L, Fowler PA, Groome NP \& Knight PG. Measurement of serum concentrations of inhibin-A $(\alpha-\beta A$ dimer) during human pregnancy. Clinical Endocrinology 1995 42 391-397.

12 Muttukrishna S, Fowler PA, George L, Groome NP \& Knight PG. Changes in peripheral serum levels of total activin A during the human menstrual cycle and pregnancy. Journal of Clinical Endocrinology and Metabolism $1996 \mathbf{8 1} 3328-3334$.

13 Bischof P. Placental proteins. Contributions in Gynecology and Obstetrics 198412 6-92.

14 Hughes G, Bischof P, Wilson G, Smith R \& Klopper A. Assay of placental protein to determine fetal risk. British Medical Journal $1980 \mathbf{2 8 0} 671-673$.

15 Toop K \& Klopper A. Concentration of pregnancy-associated plasma protein A (PAPP-A) in patients with pre-eclamptic toxaemia. Placenta 19814 (Suppl) 167-174.

16 Westergaard JG \& Teisner B. Pregnancy-associated plasma protein A in normal and abnormal late pregnancy. In Pregnancy Proteins, pp 345-354. Eds JG Grudzinskas, B Teisner \& M Seppala. Sydney: Academic Press, 1982.
17 Bersinger NA, Smárason AK, Muttukrishna S, Groome NP, Redman CW \& Birkhäuser MH. PAPP-A, inhibin A, activin A and sE-selectin are increased in pre-eclampsia serum. The IFPA/8th meeting of the European Placenta Group, Schladming, Austria, 1999. Placenta 199920 A13 (Abstract).

18 Chapman MG, O'Shea RT, Jones WR \& Hillier R. Pregnancyspecific $\beta 1$-glycoprotein as a screening test for at-risk pregnancies. American Journal of Obstetrics and Gynecology $1981 \mathbf{1 4 1}$ 499-502.

19 Zhang Y, Proenca R, Maffei M, Barone M, Leopold L \& Friedman JM. Positional cloning of the mouse obese gene and its human homologue. Nature 1994372 425-432.

20 Leroy P, Dessolin S, Villageois P, Moon BC, Friedman JM, Ailhaud $\mathrm{G}$ et al. Expression of ob gene in adipose cells. Journal of Biological Chemistry $19962712365-2368$.

21 Considine RV, Sinha MK, Heiman ML, Kriauciunas A, Stephens TW, Nyce MR et al. Serum immunoreactive leptin concentrations in normal-weight and obese humans. New England Journal of Medicine $1996334292-295$.

22 Masuzaki H, Ogawa Y, Sagawa N, Hosoda K, Matsumoto T, Mise H et al. Nonadipose tissue production of leptin: leptin as a novel placenta-derived hormone in humans. Nature Medicine 19973 1029-1033.

23 Highman TJ, Friedman JE, Huston LP, Wong WW \& Catalano PM. Longitudinal changes in maternal serum leptin concentrations, body composition, and resting metabolic rate in pregnancy. American Journal of Obstetrics and Gynecology $1998 \mathbf{1 7 8}$ $1010-1015$.

24 Mise H, Sagawa N, Matsumoto T, Yura S, Nanno H, Itoh H et al. Augmented placental production of leptin in preeclampsia: possible involvement of placental hypoxia. Journal of Clinical Endocrinology and Metabolism $1998 \mathbf{8 3} 3225-3229$.

25 Sivan E, Whittaker PG, Sinha D, Homko CJ, Lin M, Reece EA et al. Leptin in human pregnancy: the relationship with gestational hormones. American Journal of Obstetrics and Gynecology 1998 $1791128-1132$.

26 Torry DS, Wang HS, Wang TH, Caudle MR \& Torry RJ. Preeclampsia is associated with reduced serum levels of placenta growth factor. American Journal of Obstetrics and Gynecology $19981791539-1544$.

27 Taylor CM, Stevens H, Anthony FW \& Wheeler T. Influence of hypoxia on vascular endothelial growth factor and chorionic gonadotrophin production in the trophoblast-derived cell lines JEG, JAr and BeWo. Placenta 199718 451-458.

28 Ahmed A, Dunk C, Ahman S \& Khaliq A. Regulation of placental vascular endothelial growth factor (VEGF) and placenta growth factor (PLGF) and soluble Flt-1 by oxygen - a review. Trophoblast Research (Placenta) 200014 S16-S24.

29 Sharkey AM, Charnock-Jones DS, Boocock CA, Brown KD \& Smith SK. Expression of mRNA for vascular endothelial growth factor in human placenta. Journal of Reproduction and Fertility $199399609-615$.

30 Roberts JM, Taylor RN \& Goldfien A. Clinical and biochemical evidence of endothelial cell dysfunction in the pregnancy syndrome pre-eclampsia. American Journal of Hypertension 19914 700-708.

31 Friedman SA, Schiff E, Emeis JJ, Dekker GA \& Sibai BM. Biochemical corroboration of endothelial involvement in severe pre-eclampsia. American Journal of Obstetrics and Gynecology $1995172202-203$.

32 Manuelpillai U, Schneider M, Dole A \& Wallace EM. Activin A and activin receptors in gestational tissue from preeclamptic pregnancies. Journal of Endocrinology 2001171 57-64.

33 Bersinger NA, Zakher A, Huber U, Pescia G \& Schneider H. A sensitive immunoassay for pregnancy-associated plasma protein A (PAPP-A): a possible first trimester method of screening for Down syndrome and other trisomies. Archives of Gynecology and Obstetrics 1995256 185-192.

34 Bersinger NA, Brandenberger AW \& Birkhäuser MH. Endometrial and placental protein markers and ovarian steroids in serum 
during in vitro fertilisation cycles. Human Reproduction 199510 2149-2154.

35 Malek A, Sager R, Lang AB \& Schneider H. Protein transport across the in vitro perfused human placenta. American Journal of Reproductive Immunology 199738 263-271.

36 Malek A, Willi A, Müller J, Sager R, Hänggi W \& Bersinger N. Capacity for hormone production of cultured trophoblast cells obtained from placentae at term and in early pregnancy. Journal of Assisted Reproduction and Genetics 200118 299-304.

37 Muttukrishna S, Groome N \& Ledger WL. Gonadotropic control of secretion of dimeric inhibins and activin A by human granulosaluteal cells in vitro. Journal of Assisted Reproduction and Genetics $1997 \mathbf{1 4} 566-573$.

38 Knight PG, Muttukrishna S \& Groome NP. Development and application of a two-site enzyme immunoassay for the determination of 'total' activin-A concentrations in serum and follicular fluid. Journal of Endocrinology $1996 \mathbf{1 4 8} 267-279$.

39 Evans LW, Muttukrishna S \& Groome NP. Development, validation, and application of an ultra sensitive two-site enzyme immuno assay for human follistatin. Journal of Endocrinology $1998156275-282$.

40 Malek A, Willi A, Müller J, Sager R, Hänggi W \& Bersinger NA. Capacity of hormone production by cultured trophoblast cells obtained from placentae at term and early pregnancy. Journal of Assisted Reproduction and Genetics $2001 \mathbf{1 8} 217-222$.

41 Obiekwe BC, Sturdee D, Cockrill BL \& Chard T. Human placental lactogen in pre-eclampsia. British Journal of Obstetrics and Gynaecology 198491 1077-1080.

42 O'Connor AE, McFarlane JR, Hayward S, Yohkaichiya T, Groome NP \& De Kretser DM. Serum activin A and follistatin concentrations during human pregnancy: a cross-sectional and longitudinal study. Human Reproduction 199914 827-832.

43 Muttukrishna S, Child TJ, Groome NP \& Ledger WL. Source of circulating levels of inhibin A, pro alpha C-containing inhibins and activin A in early pregnancy. Human Reproduction 199712 1089-1093.

44 Mohan A, Asselin J, Sargent IL, Groome NP \& Muttukrishna S. Effect of cytokines and growth factors on the secretion of inhibin A, activin A and follistatin by term placental villous trophoblasts in culture. European Journal of Endocrinology 2001145 505-511.

45 Wang Y \& Walsh SW. Placental mitochondria as a source of oxidative stress in pre-eclampsia. Placenta 199819 581-586.

$46 \mathrm{Yu} \mathrm{J}$, Shao LE, Frigon NL \& Schwall R. Induced expression of the new cytokine, activin A, in human monocytes, inhibition by glucocorticoids and retinoic acid. Immunology $1996 \mathbf{8 8}$ 368-374.

47 Muttukrishna S, Tannetta D, Groome N, Redman C \& Sargent I. Secretion of activin A by peripheral blood mononuclear cells (PBMCs) in culture and flowcytometric detection of intracytoplasmic inhibin/activin subunits and activin receptors. The international workshop on inhibins, activins, and follistatins,
Melbourne, Australia, October 2000. Molecular and Cellular Endocrinology $2001 \mathbf{1 8 0} 194$ Special Edition.

48 Jackson N, Biddolph SC, Ledger W, Groome NP \& Manek S. Inhibin expression in normal and pre-eclamptic placental tissue. International Journal of Gynecological Pathology $200019219-224$.

49 Aitken DA, McKinnon D, Crossley JA, Graham GW, Berry E, Spencer K et al. Changes in the maternal serum concentrations of PAPP-A and SP1 in Down's syndrome pregnancies between the first and second trimesters. Journal of Medical Genetics 1994 31170.

50 Bersinger NA, Marguerat P, Pescia G \& Schneider H. Pregnancyassociated plasma protein A (PAPP-A): measurement by highly sensitive and specific enzyme immunoassay, importance of firsttrimester serum determinations, and stability studies. Reproduction, Fertility and Development 19957 1419-1423.

51 Berry E, Aitken DA, Crossley JA, Macri JN \& Connor JM. Screening for Down's syndrome: changes in marker levels and detection rates between first and second trimesters. British Journal of Obstetrics and Gynaecology $1997 \mathbf{1 0 4} 811-817$.

52 Anim-Nyame N. Sooranna SR, Steer PJ \& Johnson MR. Longitudinal analysis of maternal plasma leptin concentrations during normal pregnancy and pre-eclampsia. Human Reproduction $2000152033-2036$.

53 Teppa RJ, Ness RB, Crombleholme WR \& Roberts JM. Free leptin is increased in normal pregnancy and further increased in pre-eclampsia. Metabolism $2000491043-1048$.

54 Hytinantti T, Koistinen HA, Koivisto VA, Karonen SL, Rutanen EM \& Andersson S. Increased leptin concentration in preterm infants of pre-eclamptic mothers. Archives of Disease in Childhood, Fetal and Neonatal Edition 200083 F13-F16.

55 Gonzalez RR, Simon C, Caballero-Campo P, Norman R, Chardonnens D, Devoto L et al. Leptin and reproduction. Human Reproduction Update $20006290-300$.

56 Lepercq J, Cauzac M, Lahlou N, Timsit J, Girard J, Auwerx J et al. Overexpression of placental leptin in diabetic pregnancy. Diabetes $199847847-850$.

57 Chardonnens D, Cameo P, Aubert ML, Pralong FP, Islami D, Campana A et al. Modulation of human cytotrophoblastic leptin secretion by interleukin- $1 \alpha$ and $17 \beta$-oestradiol and its effect on HCG secretion. Molecular Human Reproduction $1999 \mathbf{5}$ 1077-1082.

58 Khaliq A, Dunk C, Jiang J, Shams M, Li XF, Avecedo C et al. Hypoxia down-regulates placenta growth factor, whereas fetal growth restriction up-regulates placenta growth factor expression: molecular evidence for 'placental hyperoxia' in intrauterine growth restriction. Laboratory Investigation 199979 151-170.

Received 11 March 2002

Accepted 29 August 2002 